Original Article

\title{
HYPOGLYCEMIC AND HYPOLIPIDEMIC EFFECTS OF ANNONA MURICATA L. LEAF ETHANOL EXTRACT
}

\author{
E. SOVIA, W. RATWITA, D. WIJAYANTI, D. R. NOVIANTY
}

Pharmacology Laboratory, Faculty of Medicine, Universitas Jenderal Achmad Yani, Jl Terusan Jenderal Sudirman,Cimahi, West Java, Indonesia

Email: soviaevi@yahoo.com

Received: 30 Nov 2016 Revised and Accepted: 17 Jan 2017

\section{ABSTRACT}

Objective: The aim of this study was to investigate hypoglycemic and hypolipidemic effects of Annona muricata leaf ethanol extract. This study also investigated phytochemical analysis of the extract and improvement in the islet of Langerhans.

Methods: Hypoglycemic and hypolipidemic effects were evaluated using alloxan induced diabetic rats. Twenty-five Wistar rats devided into five groups, that are normal group, control group that induced by alloxan $125 \mathrm{mg} / \mathrm{kg}$ body weight and given CMC (carboxymethyl cellulose), and three treatment group that induced by alloxan and given Annona muricata leaf ethanol extract (AMLEE) with 50, 100 and $200 \mathrm{mg} / \mathrm{kg}$ body weight. Blood glucose and total cholesterol levels were measured before and after alloxan induction, and $21 \mathrm{~d}$ after AMLEE treatment. At the end of the study, all of the animals experiment were sacrificed for histopathological examination.

Results: Phytochemical analysis revealed that flavonoids, tannins, saponins, phytosterols and phenols were present in ethanol extract of Annona muricata L. leaf. At the end of the study, blood glucose and total cholesterol levels in all AMLEE treated group were decreased significantly ( $<<0.05$ ). Final blood glucose level in the groups that given AMLEE $50 \mathrm{mg} / \mathrm{kg}$ body weight $(86.7 \pm 14.6 \mathrm{mg} / \mathrm{dl})$ was almost the same with that of the normal group $(91.25 \pm 28.38 \mathrm{mg} / \mathrm{dl})$. The result of the histopathological examination is not showed an improvement of the islet of Langerhans in AMLEE treated groups.

Conclusion: In conclusion, the ethanol extract of Annona muricata L. leaf have hypoglycemic and hypolipidemic effects. However, there was no improvement in the islet of Langerhans damage.

Keywords: Annona muricata, Hypoglycemic, Hypolipidemic, Phytochemical, Alloxan

(C) 2016 The Authors. Published by Innovare Academic Sciences Pvt Ltd. This is an open access article under the CC BY license (http://creativecommons.org/licenses/by/4. 0/) DOI: http://dx.doi.org/10.22159/ijpps.2017v9i3.16402

\section{INTRODUCTION}

Diabetes is a disease characterised by abnormal glucose metabolism, a risk of developing microvascular complications specific to diabetes and a markedly increased risk of developing macrovascular complications [1]. Diabetes also plays an important role in the oxidative stress and abnormal lipid metabolism that leads dyslipidemia, a frequent complication of diabetes [2]. Hence, drugs that have hypoglycemic and hypolipidemic effects are very useful to manage diabetic and its complications.

Herbal remedies have been used traditionally in many parts of the world to cure several diseases. Annona muricata L. (Soursop) which belongs to the family of Annonaceae is an evergreen tree species used as traditional medicines. The plant possesses the major pharmacological activities includes cytotoxicity, antileishmanial, wound healing, and anti-microbial activity [3]. It also has been reported to have anticarcinogenic and genotoxic, antiviral, antifungal, antihelmin, analgesic and antipyretic, hypotensive, antiinflammatory, and immune enhancing effects [4 -5].

Soursop leaves are the most beneficial parts of this tree. It has the acetogenins containing compounds namely bulatacin, asimisin and squamosin [4]. Phytochemical analysis of Annona muricata leaf extract revealed the presence of secondary metabolites like tannins, steroids, and cardiac glycosides [3]. The nutrients in soursop leaves also believed to stabilize blood sugar level in the normal range that very useful for diabetics management [4]. Several studies have shown that Annona muricata leaf had antihyperglycemic activity and revealed regeneration of pancreatic islet [5-9].

Diabetogenic effect of alloxan resulted from the destruction of $\beta$ cell caused by reactive oxygen species (ROS). Alloxan generates reactive oxygen species (ROS) in a cyclic redox reaction, with its reduction product, dialuric acid. Alloxan also selectively inhibits glucose- induced insulin secretion through its ability to inhibit the beta cell glucose sensor glucokinase [10-11].

The present study was designed to evaluate the hypoglycemic and hypolipidemic effects of Annona muricata leaf ethanol extract (AMLEE) in an experimental model of diabetes alloxan rats. This study also investigated phytochemical analysis and improvement in the islet of Langerhans.

\section{MATERIALS AND METHODS}

\section{Plant material}

Annona muricata leaves were collected from Cimahi, West Java, Indonesia. The plant was identified by the Department of Biology, School of Life Science, Bandung Institute of Technology, Bandung, West Java, Indonesia.

\section{Chemicals}

Alloxan was obtained from Sigma Chemical Company (St. Louis, MO). All other chemicals and solvents are of analytical grade.

\section{Preparation of Annona muricata L. leaf ethanol extract (AMLEE)}

Annona muricata fresh leaves were air-dried at room temperature for four weeks. Two kilograms of the air-dried leaves of the plant was milled into fine powder. The powdered leaf was macerated in ethanol and extracted twice, on each occasion with 5 $\mathrm{l}$ of $70 \%$ ethanol at room temperature for $48 \mathrm{~h}$. The combined ethanol extract was concentrated in a rotary evaporator (Buchi Rotavapor R200) [6].

\section{Phytochemical screening}

Chemical tests were carried out on Annona muricata L. leaf ethanol extract for the qualitative determination of phytochemical constituents as per standard procedures [13]. 


\section{Animal experiment}

Twenty-five Wistar rats (Rattus norvegicus) weighing 150-200 g were used in this study. The rats were obtained from the animal holding of Department of Biology, School of Life Science, Bandung Institute of Technology. They were housed under standard laboratory conditions. The animals were given standard rat pellets (Rat Bio Indonesia) and tap water ad libitum.

\section{Induction of experimental diabetes}

Ethical approval was obtained from the research ethic commission team of Hasan Sadikin Hospital Bandung No.070/UN6. C1.3.2/ $\mathrm{KEPK} / \mathrm{PN} / 2015$. The rats were randomly divided into five experimental groups: A (control), B (Alloxan-treated), C (Alloxan and $50 \mathrm{mg} / \mathrm{kg}$ body weight AMLEE-treated), D (Alloxan and 100 $\mathrm{mg} / \mathrm{kg}$ body weight AMLEE-treated), and E (Alloxan and $200 \mathrm{mg} / \mathrm{kg}$ body weight AMLEE-treated). Each group consisted of five rats. Diabetes mellitus was induced (in groups B, C, D and E 'test' rats) by single intraperitoneal injection of alloxan ( $125 \mathrm{mg} / \mathrm{kg}$ body weight), freshly dissolved in $0.9 \%$ saline. Control rats were injected with only $0.9 \%$ saline intraperitoneally. The 'test' animals in groups B to E became diabetic and hyperlipidemic within $72 \mathrm{~h}$ after alloxan administration. The diabetic and hyperlipidemic state was confirmed by measuring basal blood glucose and total cholesterol concentration $72 \mathrm{~h}$ after alloxan injection. Diabetic and hyperlipidemic were allowed to develop and stabilize in these alloxan-treated rats over a period of 3-5 d. All animals in all groups were kept and maintained under laboratory conditions and were allowed free access to food (standard pellet diet) and water ad libitum. Before the commencement of our experiments, both the control normal and alloxan-treated diabetic and hyperlipidemic test rats were fasted for $8 \mathrm{~h}$, but still allowed free access to water throughout. At the end of the $8 \mathrm{~h}$ fasting period, blood glucose and total cholesterol levels of the fasted normal and alloxantreated rats were determined and recorded. Fasted alloxan-treated rats with blood glucose concentration $\geq 200 \mathrm{mg} / \mathrm{dl}$ and total cholesterol concentration $\geq 130 \mathrm{mg} / \mathrm{dl}$ were considered to be diabetic and hyperlipidemic, and used in this study. A blood sample was obtained from the tail vein of the animals and their fasting blood glucose and total cholesterol levels were determined in $\mathrm{mg} / \mathrm{dl}$ using a digital glucometer (Accu-chek ${ }^{\circledR}$ ) and cholesterol test (Easy Touch $^{\circledR}$ ). The test compound [i.e., Annona muricata leaf ethanol extract (AMLEE 50, 100 and $200 \mathrm{mg} / \mathrm{kg}$ body weight] was administered orally to the group $\mathrm{C}, \mathrm{D}$ and $\mathrm{E}$ diabetic rats. The administration of AMLEE was commenced as from the $7^{\text {th }}$-day post alloxan injections for $21 \mathrm{~d}$ [6].

\section{Histological procedures}

The animals were sacrificed by cervical dislocation. Pancreatic tissues were excised from sacrificed animals, and fixed in aqueous Bouin's solution for $48 \mathrm{~h}$ and were sequentially embedded in paraffin wax blocks according to the standard procedure, sectioned at $5 \mu$ thickness. They were further deparaffined with xylol, and histologic observations were performed after staining by Haematoxylin and Eosin. The slides were examined using light microscope at a magnification power of $\times 400$.

\section{Statistical analysis}

The data obtained were expressed as means $( \pm S D)$. The differences between the means were analyzed statistically with paired $t$ test. Values of $\mathrm{p}<0.05$ were taken to imply statistical significance and $\mathrm{p}<0.01$ to imply statistical very significant.

\section{RESULTS}

\section{Results of phytochemical analysis}

The results of preliminary phytochemical analysis of Annona muricata leaf ethanol extract were given in table 1. The results revealed that flavonoids, tannins, saponins, phytosterols, and phenols were present in the extract.

Table 1: Preliminary phytochemical analysis of Annona muricata leaf ethanol extract

\begin{tabular}{ll}
\hline Parameters & Annona muricata leaf ethanol extract \\
\hline Alkaloids & - \\
Flavonoids & + \\
Tannins & + \\
Saponins & + \\
Phytosterols & + \\
Phenols & + \\
\hline
\end{tabular}

\section{Effect of Annona muricata leaf extract on blood glucose levels}

Seventy-two hours after alloxan administration, all animals that had been treated with alloxan (group B to E) displayed hyperglycemia (blood glucose levels $\geq 200 \mathrm{mg} / \mathrm{dl}$ ). Blood glucose concentrations of the alloxan-treated experimental animals were increased significantly $(p<0.05)$. Moreover, increasing of blood glucose levels in group $B$ and $C$ are very significant $(\mathrm{p}<0.01)$ (table 2). Meanwhile, animals experiment that had not treated with alloxan (group A) did not showed significant increasing of blood glucose levels.

Table 2: Changes in blood glucose levels in control, alloxan-treated and alloxan+AMLEE-treated diabetic rats

\begin{tabular}{llllll}
\hline Treatment group & \multicolumn{2}{l}{ Blood glucose levels (mg/dl) } & $\begin{array}{l}\text { p1 } \\
\text { value }\end{array}$ & $\begin{array}{l}\text { Final blood glucose } \\
\text { levels (mg/dl) }\end{array}$ & \multicolumn{1}{c}{ p2 value } \\
\cline { 2 - 4 } & Initial & After alloxan induced & 0.852 & $91.25 \pm 28.38$ \\
Control (A) & $109.25 \pm 10.34$ & $110.50 \pm 28.10$ & 0.298 & \\
Alloxan treated (B) & $107.5 \pm 6.99$ & $305.7 \pm 51.7$ & $0.007^{*}$ & $312.75 \pm 49.63$ & 0.845 \\
Alloxan and 50 mg/kg body weight AMLEE treated (C) & $88.00 \pm 46.9$ & $303.25 \pm 33.07$ & $0.001^{*}$ & $86.7 \pm 14.6$ & $0.002^{*}$ \\
Alloxan and 100 mg/kg body weight AMLEE treated (D) & $107.00 \pm 20.34$ & $347.00 \pm 45.98$ & $0.036^{* *}$ & $148.25 \pm 56.76$ & $0.018^{* *}$ \\
Alloxan and 200 mg/kg body weight AMLEE treated (E) & $98.5 \pm 11.59$ & $305.5 \pm 88.88$ & $0.022^{* *}$ & $81.25 \pm 12.03$ & $0.014^{* *}$ \\
\hline
\end{tabular}

AMLEE: Annona muricata leaf ethanol extract, Values are expressed as means ( $\pm \mathrm{SD}$ ) of 5 rats, ${ }^{*} \mathrm{p}<0.01,{ }^{* *} \mathrm{p}<0.05$, p1: between initial and after alloxan induced blood glucose levels (paired t test), p2: between after alloxan induced and final blood glucose levels (paired $t$ test)

At the end of the study period (after $21 \mathrm{~d}$ AMLEE treatment), diabetic animals in AMLEE treated group presented decreasing of blood glucose levels significantly $(\mathrm{p}<0.05)$. Even, decreasing of blood glucose levels in the group that treated with $50 \mathrm{mg} / \mathrm{kg}$ body weight AMLEE was very significant $(\mathrm{p}<0.01)$. Final blood glucose levels in group that treated with $50 \mathrm{mg} / \mathrm{kg}$ body weight $(86.7 \pm 14.6 \mathrm{mg} / \mathrm{dl})$ and $200 \mathrm{mg} / \mathrm{kg}$ body weight AMLEE $(81.25 \pm 12.03 \mathrm{mg} / \mathrm{dl})$ almost the same with control group
$(91.25 \pm 28.38 \mathrm{mg} / \mathrm{dl})$ (table 2). The group without AMLEE treatment (group B) did not showed decreasing of blood glucose levels.

\section{Effect of Annona muricata leaf extract on total cholesterol levels}

Mean total cholesterol levels of the alloxan-treated experimental animals are shown in table 3. In our control set of experiments, pretreatment of the rats with $0.9 \%$ saline alone, total cholesterol 
levels did not significantly incresed $(\mathrm{p}>0.05)$. There was also no significant difference of total cholesterol levels between after alloxan induced with final total cholesterol levels in control group. Meanwhile, all animal experiment treated by alloxan (group B to E) showed very significant increasing of total cholesterol levels $(p<0.01)$.
After $21 \mathrm{~d}$ AMLEE treatment, total cholesterol levels decreased very significant in the group that treated with 50 and $100 \mathrm{mg} / \mathrm{kg}$ body weight AMLEE $(\mathrm{p}<0.01)$. The group that treated with $200 \mathrm{mg} / \mathrm{kg}$ body weight AMLEE also showed decreasing of total cholesterol significantly $(\mathrm{p}<0.05)$.

Table 3: Changes in total cholesterol levels in control, alloxan-treated and alloxan+AMLEE-treated diabetic rats

\begin{tabular}{|c|c|c|c|c|c|}
\hline \multirow[t]{2}{*}{ Treatment group } & \multicolumn{2}{|c|}{ Total cholesterol levels (mg/dl) } & \multirow{2}{*}{$\begin{array}{l}\text { p1 } \\
\text { value }\end{array}$} & \multirow{2}{*}{$\begin{array}{l}\text { Final total cholesterol levels } \\
\text { (mg/dl) }\end{array}$} & \multirow{2}{*}{$\begin{array}{l}\text { p2 } \\
\text { value }\end{array}$} \\
\hline & Initial & After alloxan induced & & & \\
\hline Control (A) & $117.00 \pm 11.44$ & $113.00 \pm 9.09$ & 0.467 & $117.50 \pm 5.97$ & 0.459 \\
\hline Alloxan treated (B) & $113.25 \pm 6.99$ & $167.25 \pm 6.13$ & $0.002^{*}$ & $168.25 \pm 10.37$ & 0.851 \\
\hline $\begin{array}{l}\text { Alloxan and } 50 \mathrm{mg} / \mathrm{kg} \text { body weight AMLEE } \\
\text { treated }(\mathrm{C})\end{array}$ & $113.25 \pm 12.33$ & $168.00 \pm 9.33$ & $0.002^{*}$ & $129.75 \pm 8.65$ & $0.001^{*}$ \\
\hline $\begin{array}{l}\text { Alloxan and } 100 \mathrm{mg} / \mathrm{kg} \text { body weight AMLEE } \\
\text { treated (D) }\end{array}$ & $106.75 \pm 5.31$ & $169.50 \pm 5.97$ & $0.001^{*}$ & $127.75 \pm 9.74$ & $0.001^{*}$ \\
\hline $\begin{array}{l}\text { Alloxan and } 200 \mathrm{mg} / \mathrm{kg} \text { body weight AMLEE } \\
\text { treated (E) }\end{array}$ & $104.75 \pm 5.50$ & $174.00 \pm 8.08$ & $0.002^{*}$ & $126.25 \pm 11.84$ & $0.015^{* *}$ \\
\hline
\end{tabular}

AMLEE: Annona muricata leaf ethanol extract, Values are expressed as means $( \pm S D)$ of 5 rats, ${ }^{*} p<0.01, * *$ p $<0.05$, p1: between initial and after alloxan induced cholesterol levels (paired t-test), p2: between after alloxan induced and final cholesterol levels (paired t test)

\section{Histopathological examination}

The result of the histopathological examination showed in diabetic rats with no treatment, the most consistent finding in the sections of pancreatic tissues was shrunken in the islet of Langerhans (fig. 2).

There was no evidence of degenerative and necrotic changes, also no inflammatory cell infiltration. In diabetic rats treated with AMLEE extract, there was no improvement in the size of the islet of Langerhans (fig. 3-5).

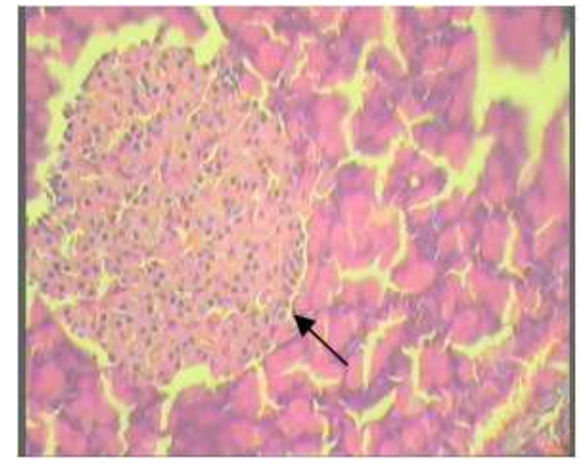

Fig. 1: Histopathological examination control shows the normal size of the islet of Langerhans. (H\&E X 400)

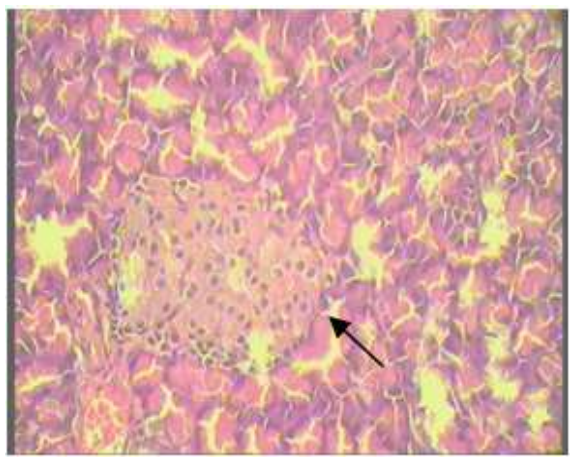

Fig. 2: Histopathological examination of alloxan-treated shows shrunken in the islet of Langerhans There were no evidence of degenerative and necrotic changes, also no inflammatory cell infiltration (H\&E X 400)

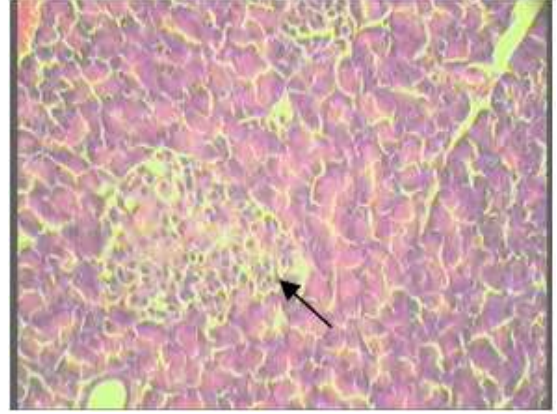

Fig. 3: Histopathological examination of alloxan+AMLEE 50 $\mathrm{mg} / \mathrm{kg}$ body weight treated shows shrunken in the islet of Langerhans (H\&E X 400)

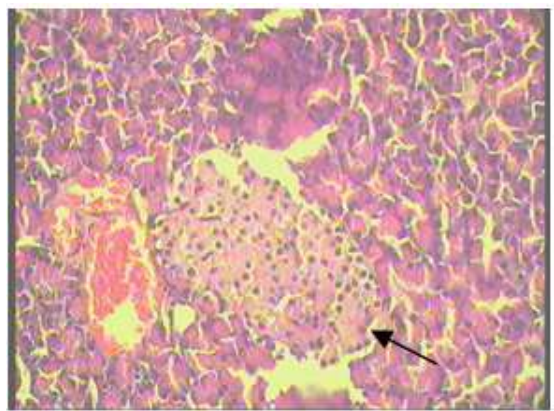

Fig. 4: Histopathological examination of alloxan+AMLEE 100 $\mathrm{mg} / \mathrm{kg}$ body weight treated shows shrunken in the islet of Langerhans (H\&E X 400)

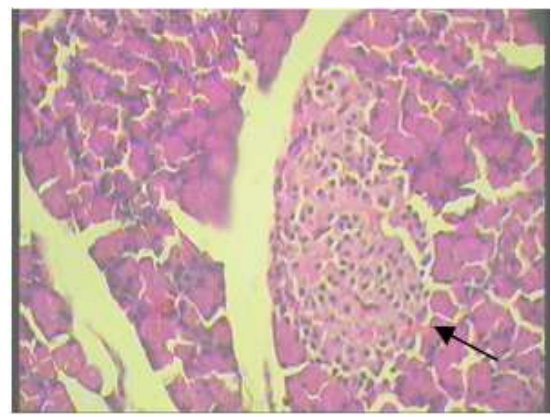

Fig. 5: Histopathological examination of alloxan+AMLEE 200 $\mathrm{mg} / \mathrm{kg}$ body weight treated shows shrunken in the islet of Langerhans (H\&E X 400) 


\section{DISCUSSION}

The utilizing of plants, plants extract, and the active compound from plants to cure diseases is very potential step in new drugs discovery [14]. The aim of this study was to demonstrate the efficacy of Annona muricata leaf ethanol extract in the reduction of blood glucose and total cholesterol levels. The study also determines phytochemical screening of the extract and the recovery in the islet of Langerhans in alloxan-treated rats.

All parts of Annona muricata plant have been used empirically as herbal medicine, including the bark, leaves, roots, fruit, and seeds [4]. Prior study suggested that Annona muricata leaf has benefit effect for diabetes [5-9], hence this study used leaf extract of Annona muricata. Previous study using aqueous [5, 9] and methanol [6-8] as extract solvent. This study using ethanol to produce Annona muricata leaves extract because ethanol has higher activity than aqueous with the result that the presence of higher amount of polyphenols, additionally ethanol was easier to penetrate the cellular membrane to extract the intracellular ingredient from plant material. Methanol is more polar than ethanol, but it has a cytotoxic effect [13]. The ethanolic extract of Annona muricata also known could reduced serum uric acid level [15].

Phytochemicals are substances found in plants that exhibit a potential for modulating human metabolism in a manner beneficial for the prevention of chronic and degenerative diseases [16]. The presence of flavonoids, tannins, saponins, phytosterols and phenolic in the extract may contribute the hypoglycemic and hypolipidemic effect. The results were supported the previous study that indicated the presence of secondary metabolites like tannins, steroids, cardiac glycosides in Annona muricata L. leaf extract [3]. Sterols that have been isolated from Annona muricata are $\beta$ sitosterone, $\beta$ sitosteryl fatty acid ester, and $\beta$ sitosterole, whereas hypoglycemic effect caused by $\beta$ sitosterone activities [17].

AMLEE administration caused decreasing of blood glucose levels in alloxan induced rats, with the result that AMLEE has a hypoglycemic effect. Hypoglycemic effect of Annona muricata leaves extract due to flavonoids role, that present in the extract. Flavonoids increasing insulin secretion as well as preventing beta-cell apoptosis, and modulation of proliferation [18]. Flavonoids also have been reported to stimulate $\mathrm{Ca} 2+$ uptake from isolated islet cells, hence it also effective even in non-insulin dependent diabetes [19].

In this study, alloxan administration only caused shrunken in the islet of Langerhans. There was no evidence of degenerative and necrotic changes, and also no inflammatory cell infiltration. The results of the study were a difference with the previous study that showed insulitis and destroying of beta cells in $150 \mathrm{mg} / \mathrm{kg}$ body weight alloxan administration [20]. Other study that using alloxan $140 \mathrm{mg} / \mathrm{kg}$ body weight also showed beta cells destruction, ballooning, picnosis, and necrosis [21]. Alloxan has two different effects: it selectively inhibits glucose-induced insulin secretion through specific inhibition of glucokinase and it causes a state of insulin-dependent diabetes through its ability to induce ROS formation, resulting in selective necrosis of beta cells [11]. This study using $125 \mathrm{mg} / \mathrm{kg}$ body weight dose of alloxan. Therefore in was suggested that the destroying of beta cells might be not occurred yet. However, the blood glucose level was already increased.

AMLEE administration also could not repaired islet of Langerhans in alloxan induced diabetic rats. The previous study indicates that Annona muricata leaves aqueous extract showed a remarkable improvement in the islet of Langerhans in Streptozotocin-induced diabetes and also could protected and preserved pancreatic $\beta$ cell integrity from oxidative stress [5-7].

However administration of AMLEE producing a significant hypoglycaemia, it was suggested that the mechanism of action of AMLEE must be operating through a different mechanism.

The result of this study also showed that ethanol extract of Annona muricata leaf had a hypolipidemic effect. Recently, certain medicinal plants have been used to treating hyperlipidemia and reducing the risk of heart attacks [22]. Study of the hypolipidemic effect of Annona muricata leaf is very limited. The previous study showed that ethanolic extract of Annona muricata bark has hypolipidemic activity in addition of hypoglycemic activity [2]. Hypolipidemic effect of Annona muricata extracts often associated with its antidiabetic and antioxidant effects [10]. Phytochemicals identified from traditional medicinal plants present an exciting opportunity for the development of newer therapeutics for the treatment of hyperlipidemia [23]. The flavonoid, that present in the extract, plays an important role in the hypolipidemic effect of Annona muricata, it has protected effect of LDL against oxidative modifications. Flavonoid consumption prevents many cardiovascular diseases including hypertension and atherosclerosis [19].

\section{CONCLUSION}

The experiment results of the present study showed that Annona muricata leaf ethanol extract has hypoglycemic and hypolipidemic effects. The extract contains some phytochemical compound that may contribute its activities. However, the extract not showed amelioration in the pancreatic islet. This study supported the traditional usage of this plant leaves as a hypoglycemic and hypolipidemic agent.

\section{ACKNOWLEDGMENT}

The authors are grateful to Directorate General of Higher Education, the Republic of Indonesia for providing Fundamental Grant for this study.

\section{CONFLICT OF INTERESTS}

The authors declare that they have no competiting of interests

\section{REFERENCES}

1. Johnsen K. New definitions of diabetes: consequences. In: Pharmacotherapy of diabetes: new developments. New York. Springer; 2007. p. 9-17.

2. Ahalya B, Shankar KR, Kiranmayi GVN. Exploration of antihyperglycemic and hypolipidemic activities of ethanolic extract of Annona muricata bark in alloxan induced diabetic rats. Int J Pharm Sci Rev Res 2014;25:21-7.

3. Gajalakshmi S, Vijayalakshmi S, Devi Rajeswari V. Phytochemical and pharmacological properties of Annona muricata: a review. Int J Pharm Pharm Sci 2012;4:13-6.

4. Sawant R, Dongre TP. Biochemical compositional analysis of Annona muricata: a miracle fruit's review. Int J Univers Pharm Bio Sci 2014;3:82-104.

5. Suneel Kumar A, Venkatarathanamma V, Naga Saibabu V, Seetha Ram K. Antipyretic activity of Annona plants leaves on brewer's yeast induced febrile rats. Asian J Pharm Clin Res 2015;8:210-2.

6. Adewole SO, Caxton-martins EA. Morphological changes and hypoglycemic effects of Annona muricata linn. (Annonaceae) leaf aqueous extract on pancreatic $\beta$-cells of streptozotocintreated diabetic rats. Afr J Biomed Res 2006;9:173-87.

7. Adeyemi DO, Komolafe OA, Adewole SO, Obuotor EM. Histomorphological and morphometric studies of the pancreatic islet cells of diabetic rats treated with extracts of Annona muricata. Folia Morphol 2010;69:92-100.

8. Adeyemi DO, Komolafe OA, Adewole SO, Obuotor EM. Effects of Annona muricata (Linn) on the morphology of pancreatic islet cells of experimentally-induced diabetic wistar rats. Internet J Altern Med 2007;5:1-8.

9. Adeyemi DO, Komolafe O, Adewole SO, Obuotor EM. Anti hyperglycemic activities of Annona muricata (Linn). Afr J Tradit Complementary Altern Med 2009:6:62-9.

10. Florence NT, Benoit MZ, Jonas K, Alexandra, Désiré DDP, Pierre $\mathrm{K}$, et al. Antidiabetic and antioxidant effects of Annona muricata (Annonaceae), aqueous extract on streptozotocin-induced diabetic rats. J Ethnopharmacol 2014;151:784-90.

11. Lenzen S. The mechanisms of alloxan and streptozotocininduced diabetes. Diabetologia 2008;51:216-26.

12. Szkudelski T. The mechanism of alloxan and streptozotocin action in b cells of the rat pancreas. Physiol Res 2001;50:536-46.

13. Tiwari H, Kumar P, Kaur B, Kaur M, Kaur G. Phytochemical screening and extraction: a review. Int Pharm Sci 2011;1:98-106.

14. Rupeshkumar M, Kavitha K, Haldar PK. The role of herbal plants in the diabetes mellitus therapy : an overview. Int J Appl Pharm 2014;6:1-3. 
15. Sunarni T, Leviana F, Fidrianny I, Iwo MI, Wirasutisna KR. The antihyperuricemic activity of four plants annonaceae using hyperuricemic rats model and enzyme assay. Asian J Pharm Clin Res 2015;8:250-3.

16. Tripoli MG, Guardia ML, Giammanco S, Majo DD. Citrus flavonoids: molecular structure, biological activity and nutritional properties: a review. Food Chem 2007;104:466-79.

17. Ragasa CY, Torres OB, Soriano G. Sterols and triterpenes from the fruit of Annona muricata Linn. Silliman J 2013;54:107-12.

18. Castell A, Baiges I, Ard A. Bioactivity of flavonoids on cells. Compr Rev Food Sci Food Saf 2008;7:299-308.

19. Sandhar P, Kumar HK, Prasher B, Tiwari T, Salhan P, Sharma M. A review of phytochemistry and pharmacology of flavonoids. Int Pharm Sci 2011:1:25-41.

20. Eliakim-Ikechukwu CF, Obri AI. Histological changes in the pancreas following administration of ethanolic extract of
Alchornea cordifolia leaf in alloxan-induced diabetic wistar rats Niger J Physiol Sci 2009;24:153-5.

21. Saha D, Ghosh SK, Das T, Mishra SB. Hypoglycemic and antihyperlipidemic effects of Adiantum caudatum in alloxan induced diabetes in rats. Asian J Pharm Clin Res 2016;9:361-3.

22. Verma N. Introduction to hyperlipidemia and its management: a review. Int J Curr Pharm Res 2017;9:6-14.

23. Singh AK, Chawla V, Saraf SK. Different chemical, biological and molecular approaches for antihyperlipidemic therapy with special emphasis on anti-hyperlipidemic agents of natural origin. J Crit Rev 2014;1:1-9.

How to cite this article

- $\quad$ E Sovia, W Ratwita, D Wijayanti, DR Novianty. Hypoglycemic and hypolipidemic effects of Annona muricata L. leaf ethanol extract. Int J Pharm Pharm Sci 2017;9(3):170-174. 